\title{
Directions for Sanitation-Based Environmental Structuring using AHP for the Prevention of Diarrhea in Pagar Alam City - Indonesia
}

\author{
Erpita Yanti, Dedi Hermon, Eri Barlian, Indang Dewata, Iswandi Umar
}

\begin{abstract}
Pagar Alam City is one of the cities in South Sumatera province which has a high number of people who are quite and fluctuating diarrhea caused by poor environmental sanitation. The research aims to produce a direction for the arrangement of a sanitary-based environment for diarrhea prevention in Pagar Alam City. This research is a qualitative study with an analysis of Analytical Hierarchy Process (AHP) which emphasizes comparative judgment based on data and literature study. From interviews and literature studies, there are three important criteria for structuring a sanitation-based environment, namely society, environment, and infrastructure. From these criteria, there are eight alternative policies related to the arrangement of sanitation based environment for diarrhea prevention, with priority as follows: Environment sanitation Program based on a case study, strengthening community empowerment facilitator, improving coordination and cooperation among related agencies, rescue environment through local wisdom, improvement of infrastructure access and sanitation facilities, forming sanitation clinics incorporated in Public health center, institutional strengthening and drafting strict rules, and Monitoring and evaluation of sanitation programs.
\end{abstract}

Keywords: Diarrhea, sanitation, environmental, pagar alam.

\section{INTRODUCTION}

$\mathrm{D}$ evelopment of the health sector is directed to increase the degree of public health characterized by increased life expectancy, decreased maternal and infant mortality rates improved nutritional status and decreased pain and mortality rates caused by various diseases, both infectious diseases, and untransmitted diseases. It is in line with the international commitments outlined in the Sustainable Development Goals (SDGs). But in fact, diarrhea is one of the most common

Revised Manuscript Received on May 15, 2020.

* Correspondence Author

Erpita Yanti*, his/her Program of Diploma III Nursing and doctoral program of environmental science, Universitas Negeri Padang, Padang, Indonesia. Email: yantierpita@gmail.com

Dedi Hermon, Department of geography and doctoral program of environmental science, Universitas Negeri Padang, Padang, Indonesia. Email: dihermon006@gmail.com

Eri Barlian, department of doctoral program of environmental science, Universitas Negeri Padang, Padang, Indonesia. Email: eribarlian@unp.ac.id

Indang Dewata, Department of doctoral program of environmental science, Universitas Negeri Padang, Padang, Indonesia. Email: indangdewata@fmipa.unp.ac.id

Iswandi Umar, Department of geography and doctoral program of environmental science, Universitas Negeri Padang, Padang, Indonesia. Email: iswandi_u@yahoo.com

(c) The Authors. Published by Blue Eyes Intelligence Engineering and Sciences Publication (BEIESP). This is an open access article under the CC BY-NC-ND license (http://creativecommons.org/licenses/by-nc-nd/4.0/) diseases in the world, including Indonesia. The problem of diarrhea in Indonesia often occurs with the form of extraordinary Genesis (KLB). The results of the UNICEF and WHO report in 2009, noting that diarrhea became one of the causes of children's mortality and morbidity under the second-highest five years after Pneumonia. It is supported by the research results [1] which mentions as much as $18 \%(1.5$ million of 9 million) deaths in children under five years in the world occur because of diarrhea annually.

The occurrence of diarrhea is characterized by the frequency of abnormal bowel movements (increased) and the consistency of stools that are mushier or liquid [2]. Prolonged diarrhea can cause dehydration or lack of fluid [3]. Many factors that cause diarrhea, such as low hygiene and sanitation behavior is often the risk factor of the incidence of diarrhea [4].

Based on data from the South Sumatra Provincial Health Office in 2017, Pagar Alam City is one of the cities in South Sumatera province that has a high number of diarrhea sufferers and fluctuates, where the average is still $>1000$ cases. The number of cases of diarrhea in Pagar Alam City experienced an increase from 2010 to 2013 and decreased slightly in 2014 to 3,980. Subsequently, in 2016 it was back down to 1,057. However, in the year 2017 again increased to 2,377 cases. One of the efforts that can be done to reduce the pain rate caused by diarrhea is to conduct environmental health efforts. This environmental health business aims to improve or optimize the human environment to realize the optimal health for human beings around [6-11]. That is, people are expected to live clean and healthy. But apparently, based on the results of interviews and preliminary surveys are carried out that the community in Pagar Alam City still has awareness for a clean and healthy life that is relatively low. One cause of the condition is a less qualified environmental health condition, especially for some residents who live in the river. They have not been able to meet the clean and healthy living standards seen from the low coverage of the population who use and utilize environmental health facilities. Based on data from the health office of Pagar Alam in 2014, it is known that of Pagar Alam City with a population of 133,862 people who have sustainable access to quality (decent) drinking water only $37.6 \%$ or 50,400 inhabitants. Then in the same year only 48,878 inhabitants with access to decent sanitation facilities (Healthy latrines), the rest still have unworthy sanitation. Improper sanitation can increase the occurrence of diarrheal disease. This is following the research results [12] stating that the disposal of faeces that do not meet sanitary requirements, will increase the risk of diarrhea in children at 2.55 fold.

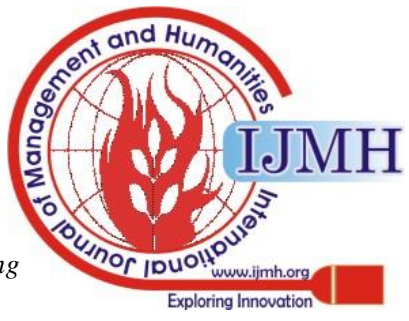




\section{Directions for Sanitation-Based Environmental Structuring Using AHP for the Prevention of Diarrhea in Pagar Alam City - Indonesia}

In addition to the condition, it turns out that garbage also affects diarrhea. [13] Research in 2017 mentions that there is a link between the disposal of waste with the incidence of diarrhea in infants. [14] at the edge of the land also show poor environmental sanitation including the disposal of any garbage that can affect the incidence of diarrhea in infants significantly. Based on the results of research conducted by [15], the results show that there is a relationship between environmental sanitation, i.e drinking water sources, the type of faeces disposal site, and the type of house floor with the incidence of diarrhea in infants in the area.

Besides, poor sanitation supported with poor personal hygiene greatly affects the increased cases of diarrhea [16]. In Pagar Alam City, there are still 33.3\% who behave not clean and unhealthy [17]. But the public will always relate to clean water and faeces disposal. Both causes of diarrhea are always integrated with human behaviour. If the environmental factors are unhealthy because of contaminated germs that are then accumulated with human behaviour is unhealthy, then food and beverages can eventually cause the incidence of diarrhea disease [18].

The amount of impact caused by poor environmental sanitation to health, especially diarrheal disease, makes the importance of setting the environment for sanitation-based communities to reduce even preventing diarrhea in Pagar Alam City. Therefore, this research aims to produce a direction of arrangement of sanitation-based environment for the prevention of diarrhea in Pagar Alam City.

\section{RESEARCH METHODOLOGY}

The research conducted in Pagar Alam City - South Sumatera Province is a qualitative study conducted through surveys to the community environment and interviews with experts from the Environmental Agency of South Sumatra province, the water resource Management Office of South Sumatera Province, the office of Cipta Karya and spatial of South Sumatera Province, and the health office of South Sumatera Province. The results obtained, processed using the Software expert Choice 11 analyzed using AHP. AHP is a method to make an alternative ranking decision in choosing one of the best when the decision-maker and has a wide range of criteria $[9,19]$. The results of the questionnaire that has been filled and processed can determine the percentage (weight) of the criteria used. This analysis is done comparative judgment based on the data and literature study obtained. The scale used is the scale of comparison interests in pairs (pairwise) according to $[9,19]$. Subsequent calculations use the index consistency formula to determine the data validation used.

Table-I: Banding Scale in Pairs

\begin{tabular}{|c|l|}
\hline Value & \multicolumn{1}{|c|}{ Description } \\
\hline 1 & Equally important \\
3 & Somewhat more important one over other \\
5 & Quite important \\
7 & Very important \\
9 & Extreme smoothness \\
$2,4,6,8$ & The Middle value between two adjacent decisions \\
\hline
\end{tabular}

Source [9, 19]

\section{RESEARCH RESULT}

Diarrhea is one of the most common diseases caused by bacteria and parasites in contaminated water. Diarrhea results in dilute faeces/liquid that causes the sufferer to be dehydrated, even death in the child diarrhea is one of the most common diseases caused by bacteria and parasites that are in polluted water. Diarrhea results in dilute faeces/liquid that causes the sufferer to dehydrate, even death in children and toddlers. Each year, as many as 842 thousand inhabitants are expected to die due to diarrhea due to unsafe consumption of drinking water [20]. One of addressing the problem of diarrhea is to pay attention to environmental sanitation.

Environmental sanitation is the way and effort of individuals or communities to monitor and control external living environments that are harmful to health and that can threaten human survival [21]. The scope of environmental sanitation includes housing, disposal of human waste (stools), provision of clean water, disposal of waste, disposal of wastewater (sewage), Livestock House (Cage), and so on [22]. In this research, environmental sanitation is focused on the disposal of human waste/stool, the supply of clean water, disposal of waste, and disposal of wastewater.

Pagar Alam City has geohydrological conditions that are traversed by several rivers including Lematang river, Selangis River, Great Selangis, Kundur river, Betung river, and Air Perikan river, while the Endikat River is a river that restricts Pagar Alam City with Kota Agung District Lahat. The condition, causing the majority of people who are on the banks of the river hang life expectancy by utilizing the need for irrigation and daily necessities.

[22] mentions that the human needs of water are very complex among others for drinking, cooking, bathing, washing and so on. Water destined for human consumption must come from a clean and safe source. However, the interviews show that the community fulfils its drinking water needs by using plumbing and groundwater through drilling or wells. This is following the data of the provincial health Office of Pagar Alam in 2014, which mentions only 37\% of the people who have sustainable access to quality drinking water (decent). It means $63 \%$ of people have difficulty obtaining clean water.

Related to healthy home conditions, turned home that has a healthy latrine, clean water facilities, landfills, wastewater disposal, good home ventilation, the density of suitable home occupancy, and the House floor is not made of land only $57.7 \%$. The rest shows still many homes with unhealthy categories. Thus, from the results of surveys and interviews with the community, it can be stated that the sanitation owned by Pagar Alam City is still in unfeasible condition, proven from:

1. There are still many places of human waste (faecal) that are not feasible

2. There are still many people who have unworthy drinking water quality

3. Society still has attitudes that reflect life is not clean and unhealthy

4. Still, there is a house with unhealthy categories.

Published By:

Blue Eyes Intelligence Engineering

\& Sciences Publication

(C) Copyright: All rights reserved. 
[20] explained that the area of intervention that can significantly prevent the incidence of diarrhea is the availability of decent water, as well as adequate sanitation and hygiene [20]. According to the decree of the Minister of Health No 829/MENKES/SK/VII/2002 that to optimize public health and efforts to support the development of health, there are a policy and strategy measures related to the implementation of health promotion activities in the environmental health sector. Therefore, to suppress the pain rate of diarrhea disease, the direction of the arrangement of sanitation based environment in Pagar Alam City focuses on 3 criteria, namely: society, environment, facilities, and infrastructure. From these criteria, the alternative policy is obtained as follows:

1. Establishment of a sanitation clinic incorporated in the Public health centre
2. Strengthening Community Empowerment Facilitator

3. Improvement of infrastructure access and sanitation facilities

4. Institutional strengthening and structuring strict rules

5. Monitoring and evaluation of sanitation programs

6. Improved coordination and cooperation among related agencies

7. Environmental sanitation Program based on case studies

8. Environmental rescue through local wisdom

The Hierarchy of the arrangement of sanitation based environment in Pagar Alam City consists of policy objectives, policy criteria and the alternative policy that is fully seen in Fig. 1, where all alternative policies will be related to the criteria and criteria arranged by the objectives.

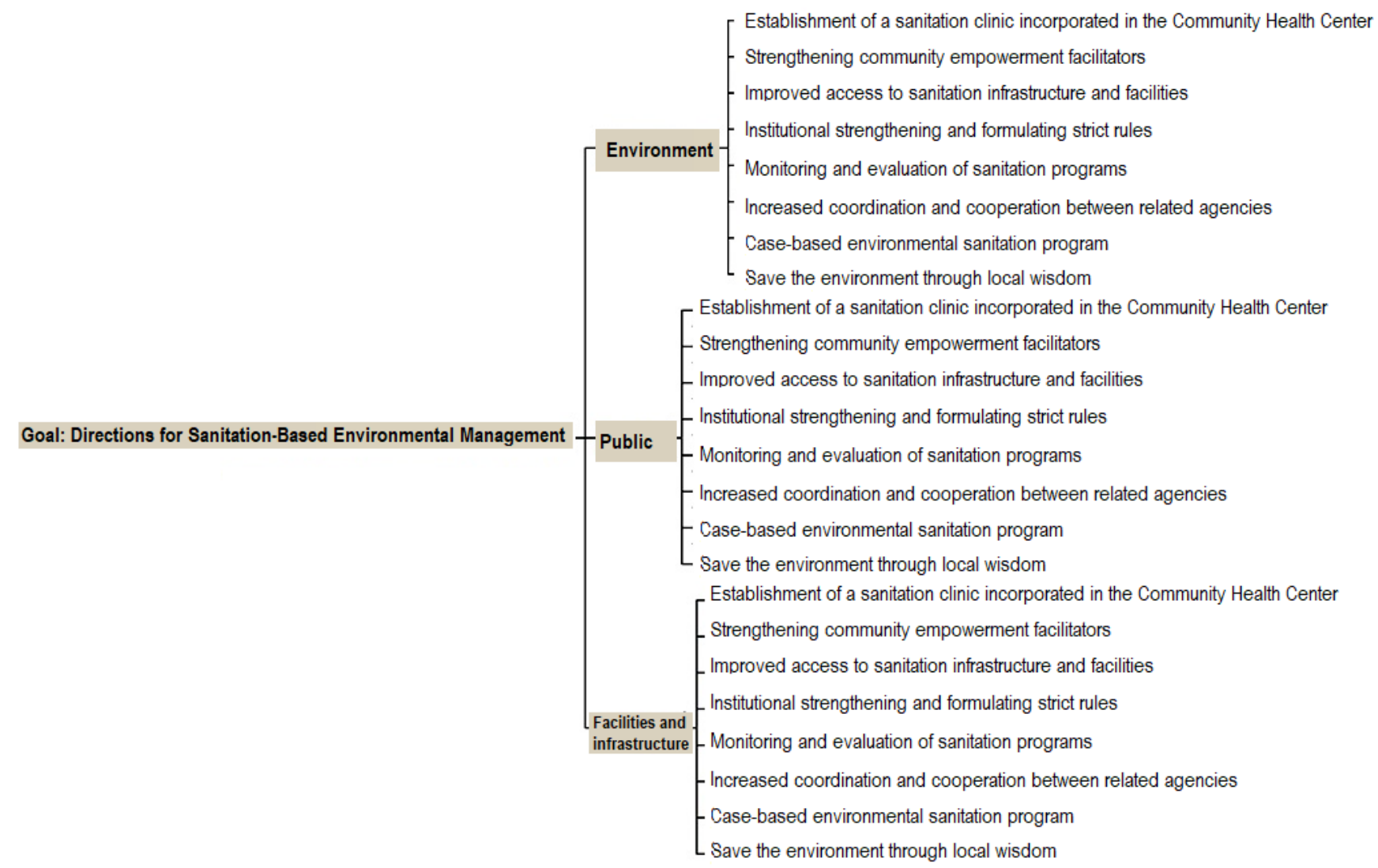

Fig. 1. Policy Hierarchy

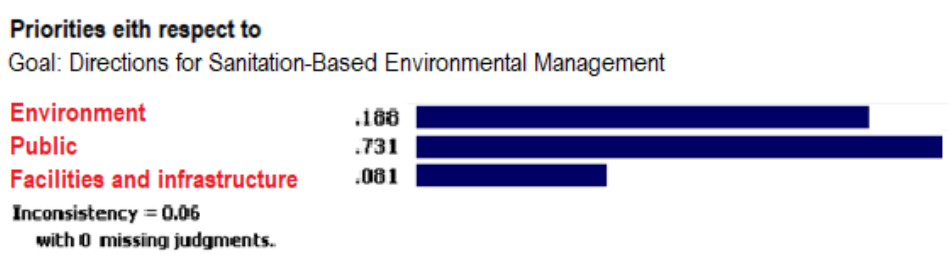

Fig.2. Weight of Interest Between Criteria and Consistency Policy

Fig. 2 Results obtained from expert choice calculations, if sorted by high-weight to low based on expert opinion. Community criteria are the highest choice for the preparation of the arrangement of sanitation based environment for diarrhea Prevention in the city of Pagar Aam. This criterion indicates that the solution in the completion of sanitation problems to prevent diarrhea depends on the behaviour of the community. If the attitudes of the community change into a clean and healthy life behaviour, then the environment is changing and the utilization/maintenance of facilities and infrastructure will be optimal.
Published By

Blue Eyes Intelligence Engineering

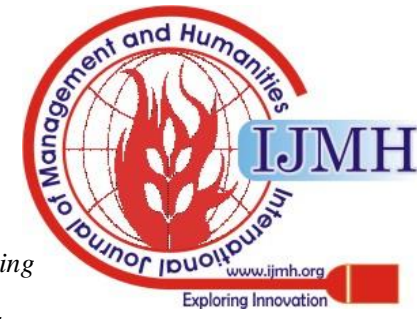

(C) Copyright: All rights reserved. 


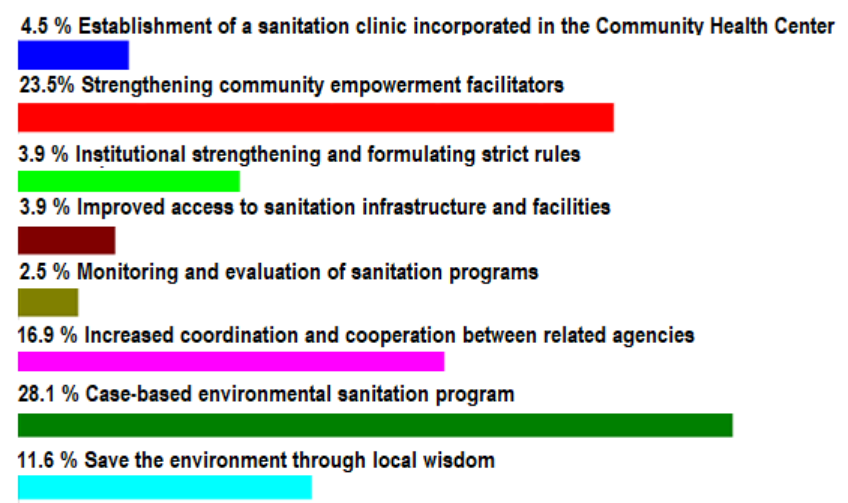

Fig. 3. Policy Priorities

Of the eight alternative related policies, the policy will be obtained as a priority in succession as follows: environmental sanitation Program based on case studies (28.1\%), strengthening community empowerment facilitators (23.5\%), improved coordination and cooperation between related agencies (16.9\%), environmental rescue through local wisdom (11.6\%), increased access to infrastructure and sanitation facilities (8.9\%), forming a sanitation clinic incorporated in the Public health center (4.5\%), strengthening institutional and drafting strict rules (3.9\%), and Monitoring and evaluation of sanitation programs (2.5\%). Three policies that are prioritizing in drafting a sanitation-based environment setup can be realized with the following strategies:

1. Environmental sanitation Program based on case studies

2. Strengthening Community Empowerment Facilitator

3. Improved coordination and cooperation among related agencies

The priorities and strategies of the policy, are very important to note and implement, especially considering the existence of unworthy latrines and people who utilize water well to drink more than tap water. The results showed children have the risk of diarrhea from households using open wells for recorded drinking water 34\% higher compared to children from households who use water, 66\% in children from families who do defecation in rivers or gutters compared to those in households with private toilet facilities and septic tanks [23].

With the implementation of all three policy priorities, then known to supply clean water can reduce the risk of $25 \%$, the utilization of the bridge lowers the risk of $32 \%$, treatment of household drinking water lowers the risk by $39 \%$ and handwashing disposable soap lowers the risk by $45 \%$ [24] but the applicability of all of the above can reduce the risk by $97 \%$ So the water is clean and the latrines are worth needed to suppress the pain rate due to diarrhea.

\section{CONCLUSION}

Pagar Alam City is one of the cities in South Sumatera province which has a high number of people who are quite and fluctuating diarrhea caused by poor environmental sanitation. Overcoming the problem above, need to be prepared to set up sanitation based environment. The arrangement of the environment, compiled from three criteria, namely society, environment, and infrastructure. From these criteria, there are eight alternative policies related to the arrangement of sanitation-based environment for diarrhea prevention, with priority as follows: Environmental sanitation Program based on the case study, strengthening community empowerment facilitator, improving coordination and cooperation among related agencies, rescue environment through local wisdom, improvement of infrastructure access and sanitation facilities, forming sanitation clinics incorporated in public health centres, institutional strengthening and drafting strict rules, and Monitoring and evaluation of sanitation programs.

\section{ACKNOWLEDGEMENT}

This research was supported by Universitas Negeri Padang (UNP) and Pagar Alam City Government. We also thank of Chairman of Postgraduate UNP and Students involved in research for their support in this research.

\section{REFERENCES}

1. G. Njeri and M. Moses, 2013. Household Choice of Diarrhea Treatments for Children Under The Age of Five In Kenya: Evidence From The Kenya Demographic And Health Survey 2008-09. European Scientific Journal. Vol. 9 No. 6, pp.77-91, 2013

2. N.A. Palancoi, Hubungan antara Pengetahuan dan Lingkungan dengan Kejadian Diare Akut pada Anak di Kelurahan Pabbundukang Kecamatan Pangkajene Kabupaten Pangkep. Jurnal Kesehatan, Vol. 7, Issue. 2, 2014

3. A.M. Dimyati, Hubungan Sanitasi Dasar Dengan Kejadian Diare Pada Masyarakat Di Kelurahan Kesumajaya Kecamatan Bekri Kabupaten Lampung Tengah Provinsi Lampung Tahun 2019 (Doctoral dissertation, poltekkes tanjungkarang), 2019

4. A. Mulyanto, I. Mujahid and T.U. Khasanah, (2018). Kemampuan Air Kelapa Muda Sebagai Antimikroba Terhadap Bakteri Escherichia coli Penyebab Diare. BIO-SITE| Biologi dan Sains Terapan, Vol. 4, Issue. 1, pp.18-24, 2018

5. R.Z. Goetzel, R.J. Ozminkowski, L.I. Sederer and T.L, The business case for quality mental health services: why employers should care about the mental health and well-being of their employees. Journal of occupational and environmental medicine, Vol. 44, Issue. 4, pp.320-330, 2002

6. D. Hermon, Mitigation and Adaptation: Disaster of Climate Change. Sara Book Publication. India, 2019

7. Hermon, D., Putra, A and Oktorie, O. Suitability Evaluation of Space Utilization Based on Enviromental Sustainability at The Coastal Area of Bungus Bay in Padang City, Indonesia. International Journal, Vol.14 No.41, pp. 193-202. 2018

\section{Published By:}

Blue Eyes Intelligence Engineering

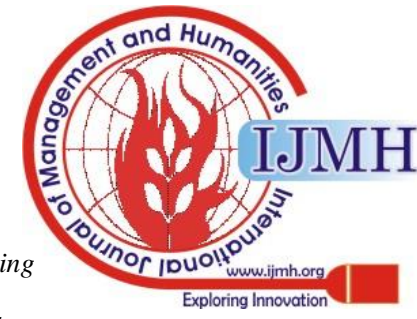


8. D. Hermon, Evaluation of physical development of the coastal tourism regions on tsunami potentially zones in Pariaman City-Indonesia. International Journal of GEOMATE, Vol. 17, Issue. 59, pp.189-196, 2019.

9. Hermon, D., Ganefri, Erianjoni, I. Dewata, P. Iskarni and A. Syam, A Policy Model of Adaptation Mitigation and Social Risks The Volcano Eruption Disaster of Sinabung in Karo Regency-Indonesia. International Journal of GEOMATE, Vol.17, No.60, pp190-196. 2019

10. Arlym, L., D. Hermon, D. Lanin, O. Oktorie and A. Putra. A Policy Model of Preparedness The General Hospital in Reducing Victims of Earthquake and Tsunami Disasters in Siberut Mentawai Island, Indonesia. International Journal of Recent Technology and Engineering (IJRTE). Vol. 8. Issue 3. 2019

11. Nurvia, F., 2011. Hubungan Sanitasi Lingkungan dengan Kejadian Diare karena Infeksi pada Balita di Wilayah Kerja Puskesmas Kuta Alam Tahun 2010.

12. A.D. Widodo, R. Setiabudy, I.S. Timan, S. Bardosono, W. Winarta and A. Firmansyah, Pancreatic enzyme replacement therapy (PERT) in children with persistent diarrhea: avoidance of elemental diet need, accessibility and costs. Asia Pacific journal of clinical nutrition, Vol. 27, Issue. 3, pp.512, 2018

13. D.Paganini and M.B. Zimmermann, The effects of iron fortification and supplementation on the gut microbiome and diarrhea in infants and children: a review. The American journal of clinical nutrition, Vol 106(suppl_6), 1688S-1693S, 201

14. L. Marni and E. Yanti, Association of Knowledge and Attitude Between Women of Childbearing Age about Tetanus Toxoid Immunization with Tetanus Toxoid Immunization Status for Future Bride and Groom. Age (years), Vol. 21, Issue. 25, pp.26-30, 2019.

15. H. Arifin, N. Syah and E. Barlian, E, Waste Management in Kurai Taji Market Sub-District South Pariaman, Pariaman City. In IOP Conference Series: Earth and Environmental Science, Vol. 314, Issue. 1, p. 012037, 2019

16. K. Serly, S. Safitri and K. Kuswarsantyo, The Relevance of Kebagh Dance Moral Values in Improving Besemah Society Local Wisdom. International Conference on Art and Arts Education (ICAAE 2018). Atlantis PresS, 2019

17. Umar, I and I. Dewata, Arahan Kebijakan Mitigasi pada Zona Rawan Banjir Kabupaten Limapuluh Kota, Provinsi Sumatera Barat. Jurnal Pengelolaan Sumberdaya Alam dan Lingkungan (Journal of Natural Resources and Environmental Management), Vol. 8, Issue. 2, pp. 251-257, 2018

18. R. Zainul and I. Dewata, Determination of $\mathrm{pH}-\mathrm{BOD}-\mathrm{COD}$ and degradation in batang arau watersheds at Padang city. 2015

19. H. Kusnoputranto and D. Susanna, Kesehatan lingkungan. 2000

20. I. Basak and T. Saaty, Group decision making using the analytic hierarchy process. Mathematical and computer modelling, Vol.17, Issue. 4-5, pp.101-109, 1993

21. D.N. Louis, A. Perry, G. Reifenberger, A. Von Deimling, D. Figarella-Branger, W.K. Cavenee and D.W. Ellison, The 2016 World Health Organization classification of tumors of the central nervous system: a summary. Acta neuropathologica, Vol. 131, Issue. 6, pp. 803-820, 2016.

22. R.K. Chandra, Nutrition, immunity and infection: from basic knowledge of dietary manipulation of immune responses to practical application of ameliorating suffering and improving survival. Proceedings of the National Academy of Sciences, Vol. 93, Issue. 25, pp.14304-14307, 1996

23. S. Notoatmodjo, Promosi kesehatan dan ilmu perilaku. 2007.

24. O.E. Alepu, Z. Li, H.O. Ikhumhen, L. Kalakodio, E.O. Enang and G.S. Abdulmoseen, An approach on Environmental Sanitation Situation and Toilets Septic Tank Design in Urban Nigeria: A case study of Calabar South. International Journal of Waste Resources, Vol. Issue. 3, pp.1-5, 2016.

25. L. Fewtrell, R.B. Kaufmann, D. Kay, W. Enanoria, L. Haller and J.M. Colford Jr, Water, sanitation, and hygiene interventions to reduce diarrhoea in less developed countries: a systematic review and meta-analysis. The Lancet infectious diseases, Vol. 5, Issue. 1, pp. 42-52. 2005

\section{AUTHORS PROFILE}

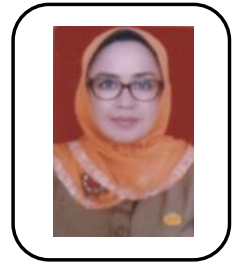

Erpita Yanti is a Research, Nurse and Lecturer of Diploma III Nursing, Universitas Negeri Padang, obtained the Master Degree in Health Management at STIE Indonesia Malang. He is actively involved in any researches regarded to environmental health and produces several scientific works in the form of SINTA-Indonesia indexed journals (ID: 6698643) Right now he is a student Doctoral Program of

Environmental Science, Universitas Negeri Padang and and as member of public relations and advocacy of the Indonesian Midwives Association Padang Pariaman 2014-2019.

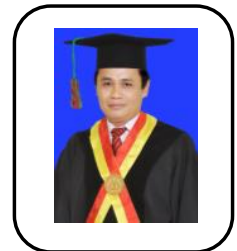

Dedi Hermon is a Professor of Disaster Geography, obtained the Doctorate Degree in Doctor Program Natural Resources Management and Environment at Bogor Agriculture University, 2009. He is actively involved in any researches regarded to natural disaster, land cover, carbon stock and produces several scientific works in the form of Scopus indexed journals (ID: 57200409691) and scientific books both national and international publications. He is assistant director of Postgraduate Universitas Negeri Padang as well as the head of Study Center of Disaster and Environment, Universitas Negeri Padang.

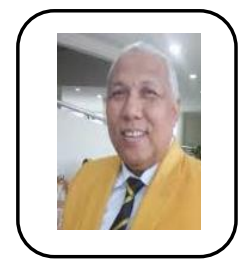

Eri Barlian is a Professor of Environmental Education, obtained the Doctorate Degree in Doctor Program Education Science at Universitas Negeri Jakarta, 1999. He is actively involved in any researches regarded to environmental education, sports, recreation and disaster and produces several scientific works in the form of Scopus indexed journals (ID: 57202293479). He is Chair of Doctoral Program of Environmental Science, Universitas Negeri Padang.

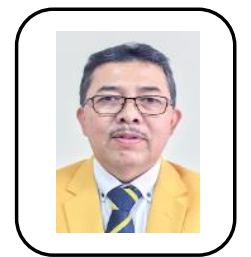

Indang Dewata is an Associate professor of Environmental Science, obtained the Doctorate Degree in Doctor Program Education Science at Universitas Indonesia, 2009. He is actively involved in any researches regarded to environmental science, chemical and produces several scientific works in the form of Scopus indexed journals (ID: 57202287960) He is Chair of Masters Program of Environmental Science, Universitas Negeri Padang.

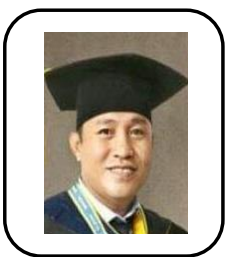

Iswandi Umar is an Associate professor of Environmental Science, obtained the Doctorate Degree in Doctor Program Natural Resources Management and Environment at Bogor Agriculture University, 2015. He is actively involved in any researches regarded to environmental science, geography and produces several scientific works in the form of Scopus indexed journals (ID: 57204825796). He is Chair of Masters Program of Geography Education, Universitas Negeri Padang.
Published By:

Blue Eyes Intelligence Engineering

\& Sciences Publication

(C) Copyright: All rights reserved.

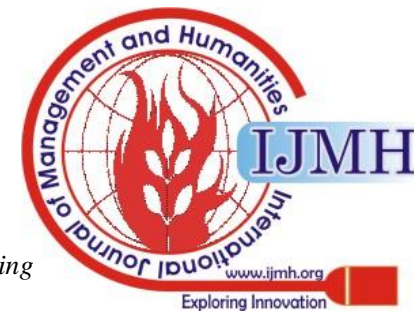

